Original Research

\title{
Long-Term Developments and Biodiversity in Carabid and Staphylinid (Coleoptera: Carabidae and Staphylinidae) Fauna during the Application of Organic Fertilizers under Agroecosystem Conditions
}

\author{
Jana Ivanič Porhajašová*, Mária Babošová, Jaroslav Noskovič, Peter Ondrišík \\ Department of Environmentalism and Zoology, Faculty of Agrobiology and Food Resources, \\ Slovak University of Agriculture in Nitra, Nitra, Slovakia
}

Received: 14 July 2017

Accepted: 18 September 2017

\begin{abstract}
The aim of this work was to ascertain the influence of applying various doses of organic fertilizers on the occurrence of the Carabidae and Staphylinidae families. The research was carried out in five treatments: 1) control treatment, 2) $25 \mathrm{t} \mathrm{ha}^{-1}$ of farmyard manure, 3) $50 \mathrm{t} \mathrm{ha}^{-1}$ of bio-sludge, 4) $50 \mathrm{t} \mathrm{ha}^{-1}$ of farmyard manure, and 5) $100 \mathrm{t} \mathrm{ha}^{-1}$ of bio-sludge. Coleoptera was represented by 87,324 individuals, Carabidae with a dominance of 80.53 to $86.28 \%$, and Staphylinidae from 5.36 to $8.32 \%$. Carabidae recorded the highest number for the $5^{\text {th }}$ treatment, for 16,534 individuals, with the lowest number being for the $4^{\text {th }}$ treatment, for 12,322 individuals. Staphylinidae recorded the highest number for the $4^{\text {th }}$ treatment, with a frequency of 1,273 individuals, and the lowest number was for the $2^{\text {nd }}$ treatment, with 934 individuals. When considering the crops grown that produce convenient individual conditions, crops producing shading, Helianthus annuus and Zea mays were preferred. The statistical evaluation did not confirm the effect of treatments, temperature, precipitation, and year of the occurrence of Carabidae. The effect of the treatment was not confirmed statistically in Staphylinidae, and the impact of the year, temperature, and precipitation were significant.
\end{abstract}

Keywords: agroecosystem, biodiversity, Carabidae, Staphylinidae, soil edaphon

*e-mail: Jana.Porhajasova@uniag.sk 


\section{Introduction}

The occurrence of edaphic animals is significantly affected by the biotic and abiotic factors present in the given biotope. Agroecosystems are characterized by the influence of natural factors, but significantly are also applied to anthropogenic interventions, such as, for instance, growth structure, soil cultivation, bringing into and applying organic or inorganic fertilizers into the soil, and others. These interventions are often involved in reducing their number [1-2]. Soil communities represent a diversified component of soil fauna. Thanks to a wide range of taxonomic groups with specific adaptations to soil habitat and by a different sensitivity to environmental stress, they are suitable for studying the influence of natural and anthropogenic disturbances on the soil environment. They are an important component of soil fauna because they participate in decomposition processes, regulate the population of soil microorganisms, some forms are pests of plants, so they have a different functional status in the soil system [3]. Throughout the long history of agriculture, many species of soil zoofauna have been adapted to the high impact of disturbances, uniformity and intensive utilization of soil [4]. The dominant group among soil animals together with Collembola, Acarina, Heteroptera and others, is represented by coleopterofauna with predominantly represented families of Carabidae and Staphylinidae. The most numerous families of Coleoptera, which occur in all terrestrial ecosystems, are the families of Carabidae and Staphylinidae [5].

Most Carabidae species are living on the surface of the soil, and some require shading or are heliophilic, occurring during the day on open habitats. These are hygrophilous species, with night activity. From the trophic point of view, they are omnivorous species, non-specialized carnivores, specialized vegetarian at the stage of a larva, but also imago. The development of the predominant majority is one year. Among factors underlying their occurrence belong moisture, temperature, shade, the type of vegetation present, and the nature of soil background [6]. There may be potential for the use of productivity and disturbance estimations in the provision of ecosystem services, especially in assessing the conditions required to optimize ground beetle activity for pest control [7]. Although soil Coleoptera represent a taxonomically diverse group and differ widely in size and ecological role, a lot of studies have focused on Carabidae and Scarabaeidae [8]. Biodiversity of Carabidae under the conditions of different types of farming was evaluated [9]. The organic system of management has shown a higher representation of Carabidae when compared with conventional management. In their work, they found a positive influence of the application of organic fertilizers on the occurrence of dominant families of Carabidae and Staphylinidae. The impact of applied doses of organic fertilizers can be evaluated positively in particular for the improvement of the soil structure, increasing the vitality and density of the crops, with which to create more suitable conditions for the present fauna [10].

Staphylinidae are characterized by their oval body and shortened wing sheaths, they prefer shadowed habitats, their activity is influenced by light intensity, their high migration ability is indicated by a strong human influence for biotopes. Their trophic relationships are more diverse than those of Carabidae. Some are predators or can be fed with organic residues, they are also mycofagous species, etc. [11-12]. The number of species and individuals of Staphylinidae is mostly higher in stable biotopes than in habitats affected by abiotic conditions (anthropogenic activity).

In general, it may be stated that the higher number of Carabidae and Staphylinidae may not always indicate its haleness and undisturbed state. The agrocenoses are often found to have higher species representation as, for example, in semi-natural habitats, since the ecological requirements of each species are decisive. Predominant in the agrocenoses are species of ubiquitous, in the undisturbed habitats predominate species with higher ecological demands and stenotop species. The species composition of the staphylinid fauna in apple and pear orchards could not be considered uniform. The environmental conditions and the soil together have a significant influence upon the richness of species, and the cumulative effects of these factors can modify even the dominant structures of the communities [12].

Since Carabidae and Staphylinidae play an indispensable role in natural and artificial biocenoses, they act as predators of many pests, they have the potential to integrate plant protection against pests, and they are applied in maintaining equilibrium and the cycle of substances and energy, and for this reason it is important to study the anthropogenic impact on the occurrence of these populations. The aim of this work is to ascertain conclusive evidence of the effect of applying specified doses of organic fertilizers (manure and bio sludge) in connection with microclimatic environmental factors and cultivated crops under agroecosystem conditions.

\section{Materials and Methods}

The collection of the epigeic component of the animals was carried out 2001-2009 on a field semioperational experiment at the experimental station of the Slovak University of Agriculture in Nitra-Kolínany, located $10 \mathrm{kms}$ northeast of the town of Nitra. The elevation above sea level of the monitored location is $160-180 \mathrm{~m}$, with the coordinates $\mathrm{N} 48^{\circ} 21^{\prime} 41^{\prime \prime} \mathrm{E}$ $18^{\circ} 12^{\prime} 37^{\prime \prime}$. The soil type is brown soil, with an average humus content of $2.149 \% \mathrm{Hm}$. According to the morphogenetic soil classification system of the Slovak Republic, we classify Haplic luvisol as a subtype, with exchangeable soil reaction $(\mathrm{pH} / \mathrm{KCL})$ as strongly acidic or acidic (4.59 to $5.39 \mathrm{pH}$ units). On this basis, 
Table 1 . The average monthly temperatures and total monthly rainfall 2001-2009.

\begin{tabular}{|c|c|c|c|c|c|c|c|c|c|c|c|c|c|c|c|c|c|}
\hline \multirow{2}{*}{$\begin{array}{l}\text { Month/ } \\
\text { Year }\end{array}$} & \multicolumn{17}{|c|}{ The average monthly temperatures $\left({ }^{\circ} \mathrm{C}\right)$} \\
\hline & $\begin{array}{c}\text { Normal } \\
1951-80\end{array}$ & 2001 & 2002 & \multicolumn{2}{|c|}{2003} & \multicolumn{2}{|c|}{2004} & \multicolumn{2}{|r|}{2005} & \multicolumn{3}{|c|}{2006} & \multicolumn{2}{|l|}{2007} & \multicolumn{2}{|l|}{2008} & 2009 \\
\hline I. & -1.7 & 0.4 & -1.2 & & & \multicolumn{2}{|c|}{-3.1} & \multicolumn{2}{|r|}{-0.1} & \multicolumn{2}{|r|}{-4.1} & & 4.4 & & \multicolumn{2}{|l|}{1.4} & -1.3 \\
\hline II. & 0.5 & 2.0 & 3.5 & & & \multicolumn{2}{|c|}{1.6} & \multicolumn{2}{|r|}{-2.7} & & -1.6 & & 5.0 & & \multicolumn{2}{|l|}{2.7} & 1.2 \\
\hline III. & 4.7 & 6.0 & 6.3 & & & \multicolumn{2}{|c|}{4.7} & \multicolumn{2}{|r|}{2.7} & & 3.5 & & 7.5 & & 5.5 & & 5.5 \\
\hline IV. & 10.1 & 10.4 & 9.9 & & & & & & 11.0 & & 11.4 & & 12.2 & & 11.0 & & 14.0 \\
\hline V. & 14.8 & 17.0 & 17.4 & & & & & & 15.2 & & 14.0 & & 16.6 & & 16.0 & & 15.5 \\
\hline VI. & 18.3 & 18.0 & 19.6 & & & & & & 18.0 & & 19.2 & & 21.1 & & 19.9 & & 17.1 \\
\hline VII. & 19.7 & 21.9 & 22.1 & & & & & & 20.5 & & 22.6 & & 22.3 & & 20.4 & & 20.6 \\
\hline VIII. & 19.2 & 23.1 & 20.8 & & & & & & 19.1 & & 16.7 & & 21.2 & & 20.5 & & 21.0 \\
\hline IX. & 15.4 & 14.8 & 14.9 & & & & & & 16.3 & & 16.6 & & 13.7 & & 15.3 & & 18.1 \\
\hline X. & 10.1 & 14.1 & 9.7 & & & & & & 10.7 & & 12.2 & & 9.9 & & 11.2 & & 10.3 \\
\hline XI & 4.9 & 3.9 & 8.0 & & & & & & 4.2 & & 7.5 & & 3.6 & & 6.7 & & 6.7 \\
\hline XII. & 0.5 & -5.1 & -0.4 & & & & & & 0.4 & & 3.2 & & -1.1 & & 3.0 & & 1.3 \\
\hline Average & 9.7 & 10.5 & 10.9 & & & & & & 9.6 & & 10.1 & & 11.4 & & 11.1 & & 10.8 \\
\hline & & & & & & al & iu & Tat & afall (1 & $\mathrm{mm})$ & & & & & & & \\
\hline Year & $\begin{array}{l}\text { Normal } \\
1951-80\end{array}$ & 2001 & & & & & & 04 & & 2005 & & 2006 & & 2007 & & 008 & 2009 \\
\hline I. & 31 & 22.9 & & & & & & .9 & & 31.0 & & 57.4 & & 66.3 & & 5.5 & 41.7 \\
\hline II. & 32 & 19.0 & & & & & & .1 & & 53.0 & & 39.0 & & 32.9 & & 0.2 & 57.3 \\
\hline III. & 33 & 50.9 & & & & & & .8 & & 3.4 & & 35.2 & & 58.0 & & 2.7 & 53.6 \\
\hline IV. & 43 & 20.0 & & & & & & .3 & & 78.7 & & 48.1 & & 0.0 & & 6.4 & 10.1 \\
\hline V. & 55 & 49.1 & & & & & & .9 & & 60.9 & & 95.6 & & 106.7 & & 5.4 & 38.1 \\
\hline VI. & 70 & 18.0 & & & & & & .8 & & 31.5 & & 63.9 & & 36.0 & & 6.2 & 79.4 \\
\hline VII. & 64 & 72.0 & & & & & & .8 & & 59.0 & & 23.7 & & 35.6 & & 0.0 & 69.8 \\
\hline VIII. & 58 & 23.8 & & & & & & .4 & & 94.5 & & 84.0 & & 78.9 & & 9.8 & 49.8 \\
\hline IX. & 37 & 101.5 & & & & & & .4 & & 47.1 & & 12.7 & & 91.2 & & 1.5 & 13.4 \\
\hline $\mathrm{X}$. & 41 & 8.3 & & & & & & .3 & & 12.1 & & 15.3 & & 31.6 & & 0.2 & 65.3 \\
\hline XI & 54 & 32.6 & & & & & & .7 & & 43.2 & & 24.4 & & 50.2 & & 3.1 & 55.4 \\
\hline XII. & 43 & 17.1 & & & & & & .8 & & 113.2 & & 7.8 & & 19.0 & & 8.0 & 47.4 \\
\hline$\Sigma$ & 561 & 435.2 & & & & & & 3.2 & & 633.0 & & 507.1 & & 606.4 & & 69.0 & 581.3 \\
\hline
\end{tabular}

the soil can be evaluated as strongly influenced by anthropogenic activity [13-14].

The territory belongs to the climatic region MT2 (slightly warm, slightly humid, with a mild winter), the sum of temperatures is $2,200-2,500^{\circ} \mathrm{C}$, with a probability of dry vegetation periods of $15-30 \%$. The model territory belongs to the maize production area with a flat terrain, share of arable land of $87 \%$, and a permanent grassland of $8 \%$ [15].

The average annual air temperature and average rainfall over the monitored period were elaborated upon on the basis of the characteristics of the agro-climatic conditions of the area (Table 1). The average annual temperature during the monitored period was $10.5^{\circ} \mathrm{C}$ and the average of total rainfall was $563.3 \mathrm{~mm}$. The tables also show the climatic standard over the period 1951-1980 [16-20].

The experiment was carried out in Kolíňany using the earth traps method (the method is based on the location of the open glass jar into the soil - 1L filled up to $1 / 3$ by fixative solution of $4 \%$ formaldehyde, earth traps were exposed within the crops and treatments during the growing season: April to October, obtained biological material was taken off in monthly intervals, 
earth traps were subsequently renewed and in terms of the department was this material determinate), which were exposed in the five treatments: the $1^{\text {st }}$ treatment was control, $2^{\text {nd }}$ treatment was $25 \mathrm{t}^{\text {hasl }}$ of farmyard manure, $3^{\text {rd }}$ treatment was $50 \mathrm{t}^{\text {has }}{ }^{\text {was }}$ of biosludge, $4^{\text {th }}$ treatment was $50 \mathrm{t}$ hawas of farmyard manure, and $5^{\text {th }}$ treatment was $100 \mathrm{t} \mathrm{ha}^{-1}$ of biosludge. The total area of the model was $9,000 \mathrm{~m}^{2}$, and each treatment had a surface area of $1,800 \mathrm{~m}^{2}$ (size of one treatment was 100 $\mathrm{x} 18 \mathrm{~m})$. Biosludge is the residual after production of biogas and the fall was applied to the soil.

Each year the traps were exposed in different crops: 2001 - Hordeum vulgare, 2002 - Beta vulgaris, 2003 - Zea mays, 2004 - Helianthus annuus, 2005 - Beta vulgaris, 2006 - Zea mays, 2007 - Beta vulgaris, 2008 Hordeum vulgare, and 2009 - Helianthus annuus.

The following indicators were evaluated in the populations obtained:

- Total amount of epigeic material (abundance).

- Determining the line coleoptera aimed at the carabidae and staphylinidae families.

- Species identity (ij), according to jaccard [21], diversity degree (d), according to Shannon-Weaver, modified according to Schwerdtfeger [22].

- Overall evaluation of the occurrence of populations and their biodiversity.

- Statistical evaluation of the results in the STATGRAPHICS 5.1 PLUS program and - since the set did not have a uniform distribution even after using transformations - the nonparametric Kruskal-Wallis test [23] was used.

\section{Results and Discussion}

The epigeic material obtained presents collections of biological material during the 9-year research period (2001-2009) using the ground traps method. From the point of view of evaluation of agroecosystems homeostasis, the Coleoptera population was selected, with model families of Carabidae and Staphylinidae, which by their presence indicate topical and trophic environmental conditions, acting as part of the mechanisms of transport of substances and energy flow and reaction sensitively to changes carried out in the agroecosystems. Owing to their biodiversity, they are suitable for detecting the effects of natural and anthropogenic disturbances [24].

The frequency of colleopterofauna for the period under investigation represented 87,324 individuals. Concerning the objective of the work, attention was directed to the dominant Carabidae family, which during the years and treatments showed the representation from 80.53 to $86.28 \%$ and Staphylinidae from 5.36 to $8.32 \%$. Both families are trophic and ecologically diverse groups occurring in all types of terrestrial ecosystems that are applied in natural biocenoses and agroecosystems due to their diversity and abundance in maintaining equilibrium in the circulations of substances and energy $[12,25]$.
On the basis of a summary evaluation of the collections during the monitored years and treatments, it can be stated that the occurrence and representation of the present families was uneven, which is related to the microclimatic conditions at the monitored locality over a longer period of time, the vegetation present, and the habitat requirements of the species present (Figs 1-5). The frequency of individuals during the period under review varied as follows:

- $1^{\text {st }}$ treatment: control treatment family Carabidae from 612 individuals to 3,832 individuals (dominance of Coleoptera 86.28\%), family Staphylinidae from 0 individuals to 188 individuals (dominance of Coleptera $5.36 \%)$.

- $2^{\text {nd }}$ treatment: $25 \mathrm{t} \mathrm{ha}^{-1}$ of the farmyard manure family Carabidae from 1,080 individuals to 3,228 individuals (dominance of Coleoptera 84.24\%), family Staphylinidae from 4 individuals to 280 individuals (dominance of Coleptera $5.44 \%$ ).

- $3^{\text {rd }}$ treatment: $50 \mathrm{t} \mathrm{ha} \mathrm{a}^{-1}$ of bio-sludge family Carabidae from 323 individuals to 4,440 individuals (dominance of Coleoptera $83.19 \%$ ), family Staphylinidae from 28 individuals to 432 individuals (dominance of Coleoptera $7.26 \%$ ).

- $4^{\text {th }}$ treatment: $50 \mathrm{t}$ ha $\mathrm{a}^{-1}$ of the farmyard manure family Carabidae from 372 individuals to 3,520 individuals (dominance of Coleptera 80.53\%), family Staphylinidae from 16 individuals to 388 individuals (dominance of Coleptera $8.32 \%$ ).

- $5^{\text {th }}$ treatment: $100 \mathrm{t} \mathrm{ha}^{-1}$ of bio-sludge family Carabidae from 404 individuals to 3,474 individuals, (dominance of Coleoptera 83.93\%), family Staphylinidae from 12 individuals to 339 individuals (dominance of Coleptera 5.59\%) (Figs 1-5).

Based on the cumulative abundance of the effect of the treatment on the occurrence of the Carabidae family, as treatment with the highest occurrence of the $5^{\text {th }}$ treatment with $100 \mathrm{t} \mathrm{ha}^{-1}$ of biosludge $(16,534$ individuals) can be evaluated, and with the lowest occurrence of the 4th treatment with $50 \mathrm{t} \mathrm{ha}^{-1}$ of the manure 12,322 individuals. The family Staphylinidae have recorded the highest frequency in the $4^{\text {th }}$ treatment - $50 \mathrm{t} \mathrm{ha}^{-1}$ of the farmyard manure (1,273 individuals) and the lowest representation was recorded by the second treatment of $25 \mathrm{t} \mathrm{ha}^{-1}$ of farmyard manure (934 individuals; Fig. 6). The relationships of communities in individual fertilization treatments and years, respectively, in crops are represented by the above graphs, high abundance values are correlated mainly with climatic factors and the vegetation present, in the case of Carabidae also by the maximum dose of biosludge, in Staphylinidae they are correlated by the application of $50 \mathrm{t} \mathrm{ha}^{-1}$ of biosludge and $50 \mathrm{t} \mathrm{ha}^{-1}$ of farmyard manure. On the contrary, the lowest values are related to Carabidae with the application of $50 \mathrm{t} \mathrm{ha}^{-1}$ of the manure and in family of Staphylinidae with the application of $25 \mathrm{t} \mathrm{ha}^{-1}$ of farmyard manure.

Despite the above given, we can say that no significant difference in the occurrence of individuals has been found. The higher number of individuals found 
in these treatments can be explained by the application of maximum doses of organic fertilizers, which have a positive influence on the soil structure and increase the vitality and density of growth, which is clearly related to the creation of more convenient conditions for the fauna present, mainly from the the point of view of shadowing. Many authors are of the opinion that the influence of the fertilizer variation on the occurrence of soil fauna is insignificant, and are of the opinion that the species present naturally migrate in agroecosystems, as has been

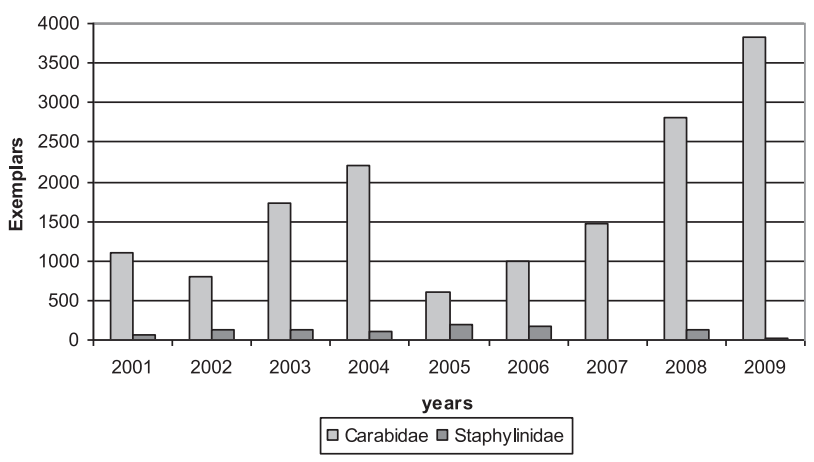

Fig. 1. $1^{\text {st }}$ treatment - control treatment: abundance the family Carabidae and Staphylinidae on the location Kolínany in 20012009.

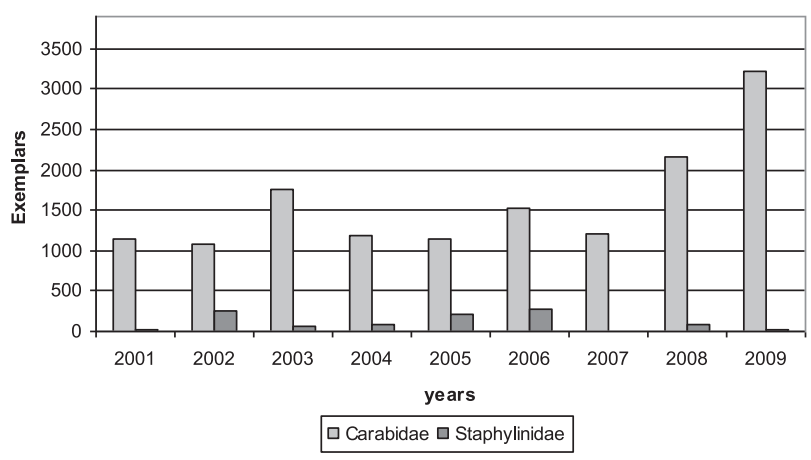

Fig. 2. $2^{\text {nd }}$ treatment $-25 \mathrm{t} \mathrm{ha}^{-1}$ of farmyard manure: abundance the family Carabidae and Staphylinidae on the location Kolínany in 2001-2009.

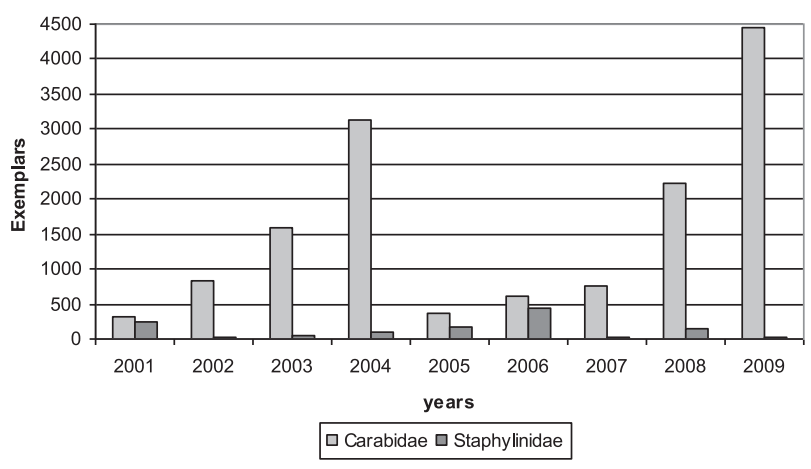

Fig. 3. $3^{\text {rd }}$ treatment $-50 \mathrm{t} \mathrm{ha}^{-1}$ of bio-sludge: abundance the family Carabidae and Staphylinidae on the location Kolínany in 2001-2009. confirmed by our findings, too [26-27]. The occurrence of species is primarily influenced by the microclimatic conditions of the environment. The presence of other, lower-represented families only adds to the richness of the zoocenosis spectrum [28-29].

Based on the cumulative abundance and dominance of the monitored populations, we can conclude that the maximum occurrence of species of the Carabidae family was recorded in 2009, in the crop Helianthus annuus, with frequency of 17,844 individuals, suitable conditions from the point of view of shadowing and moisture have also been created by Hordeum vulgare

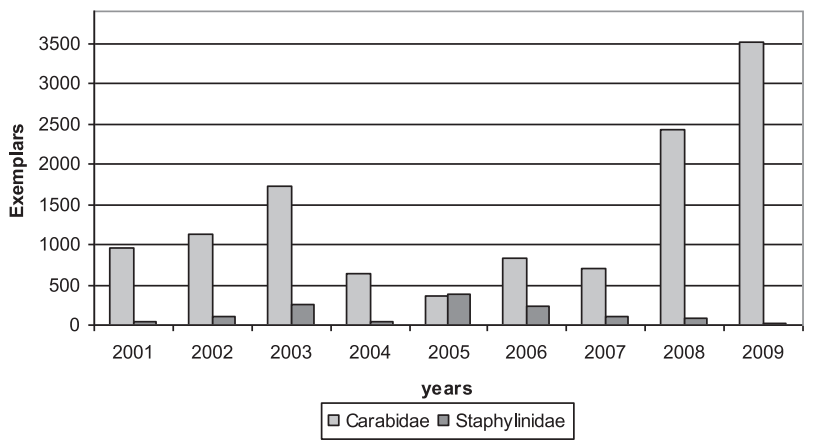

Fig. 4. $4^{\text {th }}$ treatment $-50 \mathrm{t} \mathrm{ha}^{-1}$ of farmyard manure: abundance the family Carabidae and Staphylinidae on the location Kolínany in 2001-2009.

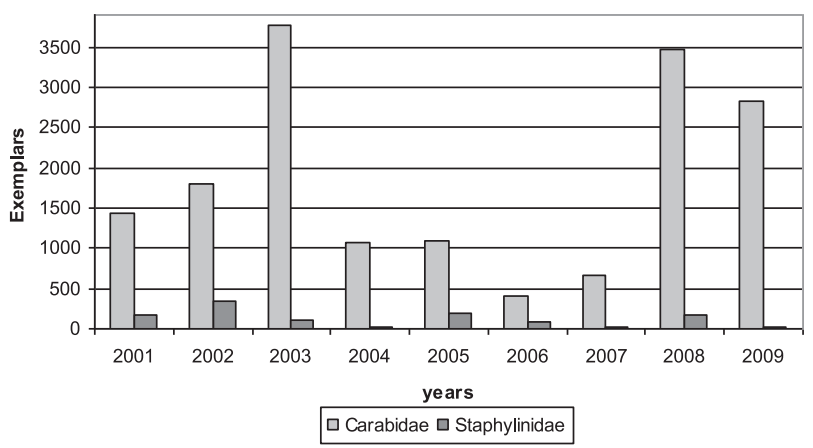

Fig. 5. $5^{\text {th }}$ treatment $-100 \mathrm{tha}^{-1}$ of bio-sludge: abundance the family Carabidae and Staphylinidae on the location Kolínany in 2001-2009.

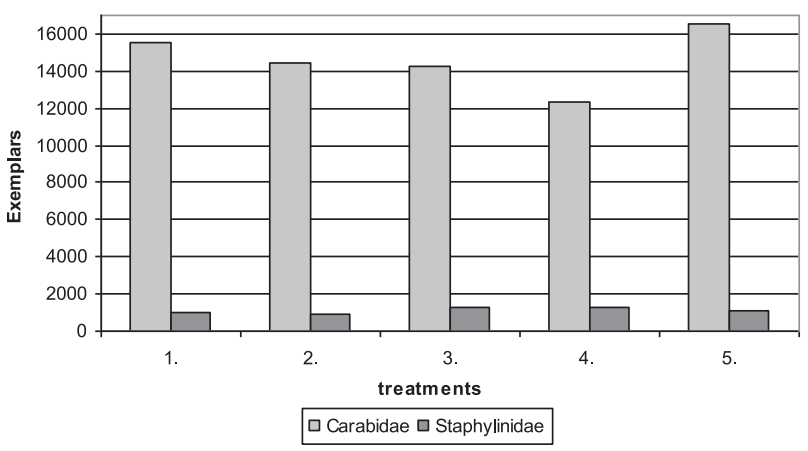

Fig. 6. abundance the family Carabidae and Staphylinidae on the location Kolíñany in 2001-2009, on individual treatments. 
and Zea mays. The lowest frequency (3,572 individuals) was found in the crop Beta vulgaris. This confirms that the most important factors determining the occurrence of Carabidae are moisture, temperature, shadowing, and vegetation, which has also been confirmed by our findings [6-7]. Besides the microclimatic conditions and vegetation type, it is worth mentioning the objective of our work - namely to ascertain the influence of the application of organic fertilizers, which in our case has positively influenced the number of individuals despite the fact that the statistical evaluation has not been confirmed. On the basis of the Kruskal-Wallis statistical evaluation test for the dependence of the occurrence of families on individual factors, it was found that the dependence of occurrence of the Carabidae family on year (0.12493), treatment $(0.40151)$, temperature (0.12493), and precipitation (0.12493) were insignificant $(\mathrm{P}>0.05)$. Based on the above it can be stated that the observed factors did not have a significant impact on the occurrence of the Carabidae.

The Staphylinidae family was represented in a lower frequency, but still at the level of dominant occurrence, where the maximum incidence was recorded in 2006 with a frequency of 1,184 individuals (crop Zea mays) and in 2005 with a frequency of 1,124 individuals (crop Beta vulgaris). The lowest frequency was recorded in 2009 with a frequency of 132 individuals (crop Helianthus annuus). Staphylinidae are species mostly active during the day, they prefer rather shadowed habitats, and their activity is influenced by light intensity. The high frequency of species with good migratory possibilities indicates a strong human impact on the habitats [6-7].

On the basis of the Kruskal-Wallis statistical evaluation test it may be stated that the effect of the variant on the occurrence of Staphylinidae was not manifested (0.68154). The influence of climatic conditions such as year (0.01873), temperature (0.01873), and precipitation (0.01873) was significant $(\mathrm{P}=0.05-0.01)$.

On the basis of correlative relationships, the Carabidae and Staphylinidae families are in mutually negative correlation, which may be explained by similar requirements on environmental conditions. The high number of Carabidae and Staphylinidae species found on the monitored locality may not always indicate the preservation and lack of disturbance of the environment. In agrocenoses the frequency is many times higher than in natural habitats, because the ecological requirements of the species present are decisive, in agrocenoses prevail ubiquitous species, while in undisturbed habitats there are species with increased ecological demands and stenotop species [12].

The occurrence of Carabidae and Staphylinidae species is closely related with their migratory capacity, especially at the time of reproduction and flexibility in searching for new habitats, habitat requirements, and cenological properties. In their absence, in our case, the family of Staphylinidae in the $1^{\text {st }}$ and $2^{\text {nd }}$ treatments (years 2007), we cannot draw conclusions about the given site. On the contrary, from its presence in other variants we follow the direct proportionality of the migratory capacity of the given species. For a reason of the hidden way of life of the Carabidae and Staphylinidae populations, they are not affected by applied insecticides, which is to be considered because, according to other authors, these two families are an example of resistance to anthropogenic effects [29]. The Staphylinidae family does not react negatively to the agronomic practices in agrocenoses [30].

The values of Jaccard index of species identity in individual years and treatments varied from 73.68 to $84.21 \%$, with the average of $79.76 \%$. Low values appeared mainly in the variants that were accompanied by a high dominance of both families. In general, it may be stated that lower values are a reflection of ecosystems that are heavily influenced by human activity [31-32].

The index diversity values calculated according to Shannon-Weaver reached 0.73829 , which is a real value considering the character of the biotope that is significantly affected by human activity. When compared to the calculated value within the Alūvium Žitava Nature reserve ecosystem, the value reached 2.12188 and is evidence of ecosystem stability [33-34]. In general, we can state that the presence of the edaphic groups is associated with a number of relatively complex relationships taking place in ecosystems.

\section{Conclusions}

The occurrence of edaphic groups of animals is dependent on the abiotic and biotic factors that are characteristic for a given habitat. Agroecosystems include, in addition to natural, anthropogenic factors (soil cultivation, crops, application of organic and inorganic fertilizers, and pesticides). All these interventions represent a risk for the edaphone present, which can be manifested mainly by decreasing the frequency.

The model epigeic groups of Coleoptera, with emphasis on the Carabidae and Staphylinidae families, can be used in detecting changes in biodiversity in ecosystems. In our case, it concerned the agroecosystem in which in the individual treatments are dominated by applied organic fertilizers, namely farmyard manure and bio-sludge at precisely specified doses, and present vegetative cover, taking into account the given microclimatic conditions of the given biotope. We can state that no significant differences have been found in connection with organic fertilizer doses, which play an important role in cultivated crops, especially in favor of crops that have generated shadowing of migration areas and have created suitable topical and trophic conditions for the given environment. 


\section{Acknowledgements}

This study was supported by project VEGA $1 / 0512 / 18$

\section{References}

1. BARANOVÁ B., FAZEKAŠOVÁ D., JÁSZAY T., MANKO P. Ground beetle (Coleoptera: Carabidae) community of arable land with different crops. Folia faunistica Slovaca, 18 (1), 21, 2013.

2. PORHAJAŠOVÁ J., ŠUSTEK Z, NOSKOVIČ J., BABOŠOVÁ M. The eefect of application of organic fertilizers on the dynamics of occurrence of Carabid species (Carabidae, Coleoptera). Journal Central European Agriculture, 14 (2), 251, 2013.

3. DIEKÖTTER T., WAMSER S., WOLTERS V., BIRKHOFER K. Landscape and management effects on structure and function of soil arthropod communities in winter wheat. Agriculture, Ecosystem \& Environment, 137, 108, 2010.

4. LIU R., ZHU F., STEINBERGER Y. Ground-active arthropod responses to raifall-induced dune microhabitats in a desertifield steppe ecosystem, China. Journal Arid Land, 8 (4), 632, 2016.

5. LAWRENCE J.F., SLIPSKI A., SEAGO A.E. Phylogeny of the Coleoptera based on morphological characters of adults and larvae. Annales Zoologici. 61 (1), 1, 2011.

6. BOHÁČ J., KOHOUT P. Methods of biodiversity evaluation on the growth of energetic plants - hemiedaphic and epigeic beetles. Acta Pruhoniciana, 97, 85, 2011.

7. EYRE M.D., LUFF M.L., LEIFERT C. Crop, field boundary, productivity and disturbance influences on ground beetles (Coleoptera, Carabidae) in the agroecosystem. Agriculture, Ecosystems and Envvironment, 165, 60, 2013.

8. BADIERITAKIS E.G., FANTINOU A.A., EMMANOUEL N.G. A faunistic study on Carabidae and Scarabaeidae in alfalfa fields from Central Greece. Biologia, 72 (11), 1274, 2016.

9. VICIAN V., SVITOK M., KOČÍK K., STAŠIOV S. The influence of agricultural management on the structure of ground beetle (Coleoptera: Carabidae) assemblages. Biologia, 70 (2), 240, 2015.

10. PORHAJAŠOVÁ J., ŠUSTEK Z., NOSKOVIČ J., BABOŠOVÁ M. The effect of application of organic fertilizers on the dynamics of occurrence of Carabid species (Carabidae, Coleoptera). Journal Central European Agriculture. 14 (2), 251, 2013.

11. CROWSON R.A. The biology of the Coleoptera. Academic Press London. 802, 1981. In: BOUCHARD, P., BOUSQUET, Y., DAVIES, A.E. et al. Family-group names in Coleoptera (Insecta). ZooKeys. 88, 1, 2011.

12. BALOG A., MARKÓ V., IMRE A. Farming system and habitat structure effects on rove beetles (Coleoptera: Staphylinidae) assembly in Central European apple and pear orchards. Biologia. 64 (2), 2009.

13. CHLPÍK J., POSPIŠIL R. Area characterization of the machanical an chemical characteristics of the soil at the research - experimental station of the Slovak University of Agriculture in Nitra, location Kolíňany. Acta fyt. et. zoot. 7, 6, 2004.

14. ŠÁLY R., BEDRNA Z., BUBLINEC E. Morphogenetic classification system of soils in Slovakia. Bratislava. 76, 2004.
15. ŠPÁNIK F., ŠIŠKA B., TOMLAIN J., REPA Š. Agroclimatic rajonization characteristics of agricultural production in Slovakia in conditions of weather changes. 15, 54, 2000.

16. REPA Š., ŠS SKKA B. The climatic characteristic of the year 2001 in Nitra. 11, 31, 2002.

17. ŠIŠKA B., REPA Š. The climatic characteristic of the year 2002 in Nitra. 12, 32, 2003.

18. REPA Š., ŠIŠKA B. The climatic characteristic of the year 2003 in Nitra. 13, 24, 2004.

19. ŠIŠKA B., ČIMO J. The climatic characteristic of the years 2004 and 2005 in Nitra. 14, 50, 2006.

20. The climatic characteristic of the years 2007, 2008, 2009 unpublished (source KBH- FZKI).

21. LOSOS B., GULIČKA J., LELLÁK J., PELIKÁN J. Animal ecology. Publishers: SPN Praha, 300, 1984.

22. SCHWERDTFEGER, F. Lehrbuch der Tierökologie. Verlag Paul Parey-Hamburg und Berlin. 384, 1978.

23. VRÁBELOVÁ M., MARKECHOVÁ D. Probability and Statistics. Publishers: FPV UKF Nitra. 199, 2001.

24. IVANIČ PORHAJAŠOVÁ, J. The abundance and spatial structure of species of the family Carabidae (Coleoptera) in condition agroecosystems. Scientific monograph. SPU Nitra. 48, 2016.

25. BOHÁČ J. Study of community structure of epigeic beetles on forest research plots. http://www.infodatasys.cz. Accessed 23 June, 2016.

26. IVANIČ PORHAJAŠOVÁ J., NOSKOVIČ J., BABOŠOVÁ M. Fluctuation families Coleoptera population depending on the organic fertilizers application. Acta fytotechnica et Zootechnica. 19 (4), 150, 2016.

27. PORHAJAŠOVÁ J., ŠUSTEK Z., NOSKOVIČ J., BABOŠOVÁ M. The effect of application of organic fertolizers on the dynamics of occurence of Carabid species (Carabidae, Coleoptera). JCEA. 14 (2) 251, 2013.

28. IRMLER U. The spatial and temporal pattern of carabid beetles on arable fields in northern Germany (SchleswingHolstein) and their value as ecological indicators. Agriculture, Ecosystems and Environment. 98, 141, 2003.

29. VARVARA M. The genus Carabus (Coleoptera, Carabidae) in some poteto crops from Romania. Oltenia. Studii si comunicari Stiintele Naturii. 26, 137, 2010.

29. ŠUSTEK Z. The effect of ACTELLIC EC 50 on the Carabidae and Staphylinidae in Norway spruce forest in the Jizerské hory mountains. Biológia. 37 (1), 131, 1982.

30. IRMLER U. Effects of Habitat and Human Activities on Species Richness and Assemblages of Staphylinidae (Coleoptera) in the Baltic Sea Coast. Journal of Entomology. 2012, 1, 2011.

31. PORHAJAŠOVÁ J. Effects of application of organic fertilizers on the spatial structure of invertebrates with accent on the family Carabidae. Habilitation work. 132, 2011.

32. PORHAJAŠOVÁ J., ŠUSTEK Z., NOSKOVIČ J., URMINSKÁ J., ONDRIŠÍK P. Spatial changes and succession of carabid communities (Coleoptera, Insecta) in seminatural wetland habitats of the Žitava river floodplain. Folia Oecologica. 37 (1), 75, 2010.

33. PORHAJAŠOVÁ J., URMINSKÁ J., NOSKOVIČ J., ONDRIŠÍK P., ŠUSTEK Z. Biodiversity of the epigeic groups in the Nature Reserve of „Alúvium Žitavy“. Acta fytotechnica et zootechnica. 12 (2), 52, 2009.

34. HULA V., ŠŤASTNÁ P. Species diversity of Carabidae (Coleoptera) in different succession stages of a limestone quarry hády (Brno, Czech Republic). Acta Univ. Agric. et Silvicult. Mendelianae Brunensis. LVIII (4), 57-64, 2010. 